\title{
A performatividade da linguagem da guerra e a guerra pela linguagem na rebelião popular chilena e na pandemia
}

\section{Yael Zaliasnik}

Universidad de Santiago

Santiago, Chile

yzaliasnik@gmail.com

orcid.org/0000-0003-2954-0687

Resumo I O texto busca investigar a performatividade da linguagem, especialmente bélica, como ponto de união e continuidade $\mathrm{da} /$ entre a rebelião popular e a crise de Sars-Cov-2 no Chile. A partir da insistência em chamar as diferentes situações de "guerra", nas quais o inimigo é "ficcionalizado" de maneiras diferentes e, em alguns aspectos, semelhantes, estratégias e desenhos de um necropoder, na concepção de Mbembe, podem ser vislumbrados, que - também através da linguagem - revela suas políticas ou a ausência de políticas ao decidir quem pode viver e como, e quem deve "ser punido", e até morrer, e como.

PALAVRAS-CHAVE:

Performatividade. Língua. Guerra.
La performatividad del lenguaje de la guerra y la guerra por el lenguaje en la rebelión popular chilena y en la pandemia

Resumen I El texto busca indagar en la performatividad del lenguaje, en especial bélico, como punto de unión y continuidad de/ entre la rebelión popular y la crisis del Sars-Cov-2 en Chile. Ya desde la insistencia de denominar "guerra" a las distintas situaciones, en las que se

"ficcionaliza" al enemigo de diferentes $y$, en algunos aspectos, parecidas ma-neras, se pueden entrever estrategias y designios de un necropoder en la concepción de Mbembe, que -también a través del lenguaje- revela sus políti-cas o ausencia de políticas decidiendo quién puede vivir y cómo y quién debe "ser castigado", e incluso morir y cómo.

PALABRAS CLAVE: Performatividad. Lenguaje. Guerra.

The performativity of the language of war and the war for language in the chilean popular rebellion and in the pandemic

Abstract | The text seeks to investigate language's performativity, especially warlike, as a point of union and continuity of/between the popular rebellion and the Sars-Cov-2 crisis in Chile. In the insistence on calling the different situations "war," with "fictionalized" enemies in diverse and, in some aspects, similar ways, strategies, and designs of a necropower can be glimpsed. In Mbembe's conception, that attitude -also through language- reveals its policies or the absence of policies deciding who and how one can live, how and who should "be punished," and even who dies and how.

KEYWORDS: Performativity. Language. War

Enviado em: $30 / 11 / 2020$

Aceptado em: 09/12/2020

Publicado em: 23/12/2020 
"A linguagem nunca foi terreno apolítico, em lugar nenhum, porque não pode ser separada do que algumas pessoas fazem com outras". (tradução livre) (MÜLLER, 2011a, p. 40)

Guerra. A palavra "guerra" carrega um fardo pesado. A palavra "guerra" está carregada. Está sempre carregada. Esse fardo não pode ser deixado de lado, ignorado, porque é parte constitutiva de si. Carregada como uma arma, como uma pistola, como uma metralhadora. Carregada como uma narrativa, como um poema, como uma canção. Carregada de imagens. De imagens e ideias. Imagens que também são "balas". Carregada inclusive de "batalhas", "inimigos", "munições". A palavra "guerra", como todas as palavras, não é indiferente. A palavra "guerra" não é neutra, inócua, inofensiva. A palavra "guerra" é uma realidade e uma metáfora. A palavra "guerra" carrega consigo outras palavras e as ideias que elas também levam, carregam, produzem e reproduzem. Porque as palavras, como John L. Austin já apontou em 1962, fazem coisas (AUSTIN, 2018). Palavras falsificam, mentem, confundem. Palavras doem, ferem, fedem, esbofeteiam, matam. Palavras acompanham, silenciam, prometem, gritam, acariciam. A palavra "guerra", por exemplo, carrega consigo a morte, implica confronto, inimigos, divisões, territórios, fronteiras, lutas, regras sociais distorcidas e esquecidas, desumanização. ${ }^{1}$

A palavra "guerra", como tantas outras, não só descreve, mas cria, impulsiona, desencadeia, liberta. Muitas vezes existem relações misteriosas não apenas entre palavras e coisas, mas também entre palavras e ações, palavras e interpretações, palavras e o que muda, palavras e poder, palavras e ausência de poder. Chantal Maillard, em "A ferida na língua" (tradução livre), refere-se a uma anedota de Friedrich Hölderlin, coletada em um poema de Paul Celan, "Tubinga, janeiro" (MAILLARD, 2015). Isolado em uma torre nas margens do rio Neckar, nos últimos anos de sua vida, Hölderlin, dizem, invariavelmente respondia "pallaksch, pallaksch" a qualquer pergunta feita, expressão em alemão que imita o balbucio de crianças pequenas. Era um mês de janeiro quando o alto comando das SS se reuniu em Tubinga para decretar o extermínio do povo judeu. A boca de quem sente, percebe e reflete às vezes não consegue fazer mais nada além de gaguejar. Retornamos então ao potencial da linguagem, mesmo quando guardada e reprimida, gaguejante.

O princípio básico da Teoria dos Atos de Fala - proposta por Austin e posteriormente incorporada à teoria linguística por John Searle (1969) - é que a linguagem é usada como extensão de ações. A linguagem não é apenas descritiva ou declarativa; pode executar muitas outras funções. Entre essas funções está o enunciado performativo, pelo qual o falante não apenas descreve uma ação, mas a executa. É o caso evidente de afirmações como "deixo meu relógio para meu irmão", "eu te batizo em nome...", "eu te prometo que..." ou "aposto que...", e menos evidentes de realidades que, de alguma forma, são interferidas pelo simples fato de escolher certas palavras em detrimento de

${ }^{1}$ Este trabalho faz parte da investigação Teatralidad de $y$ en distintos espacios de poder en Chile hoy (CONICYT FONDECYT/ INICIACIÓN FOLIO No 11170851), periodo 2017-2019. 
outras. Estes exemplos não podem ser qualificados como verdadeiros ou falsos, mas como adequados ou não adequados a certos critérios contextuais. Por meio da linguagem e do que Austin chamou de "atos de fala", frequentemente fazemos algo acontecer. Judith Butler e muitos outros teóricos irão então contar com isso para formular teorias sobre a performatividade em diferentes áreas, uma vez que esse conceito tem a ver precisamente com uma mudança, uma transformação, uma ação. Daí deriva, como aponta Homi Bhabha, sua politicidade, dado seu caráter construtivo e sua repercussão na realidade (BHABHA, 2007, p. 32). A visão do político, por outro lado, como a relação guerreira por excelência, dentro do conceito de soberania ou do "direito de matar", é abordada por Achille Mbembe, que em Necropolítica refere-se à "percepção da existência do Outro como um ataque à minha própria vida, como uma ameaça mortal ou um perigo absoluto cuja eliminação biofísica reforçaria meu potencial de vida e segurança" (2006, p. 24 - tradução livre). Para este autor, o estado de exceção aliado à relação de inimizade constitui hoje a base normativa do direito de matar. Para isso, é necessário e indispensável "ficcionalizar" o inimigo. Diferentes grupos precisam de uma guerra, e principalmente de um inimigo, para justificar sua existência, para se validarem, para se unirem e se sentirem importantes, para justificar e legitimar suas ações. Dentro dessas ações, as respostas violentas e supostamente "defensivas" ocupam um lugar central, com uma espécie de "permissão aberta" para ferir e, principalmente, para o direito de matar. Em tudo isso a linguagem pode desempenhar um papel fundamental.

Por isso, quando em 18 de outubro de 2019 uma grande e importante rebelião no Chile se tornou visível, audível e sensível, o Governo não demorou a reformular sua linguagem, recorrendo, antes de tudo, ao léxico bélico. Ao mesmo tempo, continuou a usar a boca e a mão quando em março do ano seguinte a pandemia de Sars-Cov-2 que se espalhava pelo país "desligou", de certa forma, e colocou "entre parênteses" ou "em pausa" esta rebelião. Aglomerar-se passou a ser perigoso, situação que justificava o "estado de catástrofe"2, de acordo com a classe dominante, e, com ele, os militares de volta às ruas, o toque de recolher, as quarentenas, as campanhas de "ficar em casa" e de "distanciamento social". Este último já era uma realidade atroz e óbvia no Chile muito antes deste lema, um reflexo das distâncias tremendas e intransponíveis entre diferentes pessoas e suas possibilidades de acordo com classe social e local de nascimento, entre outras características. Da mesma forma, a própria ideia de "confinamento", típica do neoliberalismo, era uma realidade evidente antes do vírus, que também isola. Como podemos ver, a pandemia (global) de Sars-Cov-2 não está apenas linear e cronologicamente ligada ao surto ou rebelião popular que começou no Chile em outubro de 2019 (embora suas causas e desencadeadores mais profundos sejam muito mais longos) ${ }^{3}$, mas também por uma série de metáforas de guerra

\footnotetext{
${ }^{2}$ Estado de exceção que foi renovado simbolicamente em 11 de setembro de 2020, dia que marcou o 470 aniversário do golpe

3 Como chamar o que começou em outubro de 2019 no Chile também não é irrelevante. "Estouro" implica algo repentino e inesperado; "revolta", uma desordem ou uma nova ordem; "rebelião", uma insurreição,
} 
cunhadas, promovidas, disseminadas pelo poder de dominação -nestas circunstâncias, o Governo -, mas "tomadas" também pelo poder de resistência, no caso de rebelião popular. Isso, por meio de um certo script que inclui arestas múltiplas e heterogêneas. Entre estas, tem-se frequentemente recorrido à linguagem da guerra, exemplo em si de uma "guerra" também para desafiar e se apropriar de certas palavras, para ressignificá-las, para usá-las e reutilizá-las, para desqualificá-las ou exaltá-las, para concedê-las ou subtrai-las um certo sentido, para compartilhá-las ou guardá-las apenas para algumas pessoas e ocasiões. Ao contrário do que está implícito na própria etimologia da expressão "pandemia" que, em suas raízes gregas antigas, é composta por "pan" (totalidade) e "dem" (gente). Todas ou quase todas as pessoas usam a linguagem para se expressar e se comunicar. Todas ou quase todas as pessoas falam, ouvem, leem, dão suas opiniões. Tudo isso através da linguagem. No entanto, essa mesma linguagem é capaz de nos colocar em caminhos opostos, de confronto, de negar uns aos outros, de nos tornarmos inimigos especialmente uma vez (auto)proclamada "guerra" (exemplo inegável da performatividade da linguagem) - num "roteiro" que assim ficcionaliza nós/eles como "inimigos", imersos em uma guerra que também é muitas vezes ficcionalizada em si mesma, a partir de uma visão mais ampla, de um determinado roteiro, de uma certa história. Assim, o que narramos ou deixamos de narrar e como o fazemos produz efeitos em um cenário maior e certamente real.

\section{A linguagem do roteiro}

O governo chileno reagiu invocando a guerra de forma clara e direta ao ver-se superado pela encenação de revolta e rebeldia demonstrada por alunos do ensino médio que, indignados com o aumento das passagens do metrô (a "ponta do iceberg", aliás, de tantas insatisfações, produto de profundos abusos e injustiças), deixaram de pagar as passagens e foram tomar as ruas. Na verdade, não há tantas interpretações possíveis quando um "estado de emergência" é decretado ${ }^{4}$. Como resultado, os representantes militares estão encarregados das diferentes "zonas de emergência", ou seja, do território do Chile. Até o dia 23 de outubro, o estado de emergência que na madrugada do dia 19 só havia sido declarado para as províncias de Santiago e Chacabuco, já havia sido ampliado para quinze das dezesseis capitais regionais. A reedição da imagem do militar na rua trouxe consigo outros traços inquestionáveis da ditadura cívico-militar, como o "toque de recolher" e a retórica de guerra.

Esses fatos, sinais, imagens e linguagem evocaram nos chilenos a memória (ou a história de outros, nas gerações mais jovens) dura, recente, inesquecível e chocante do golpe de estado de 1973 e a forma questionada e

manifestação de uma raiva que se acumulou... A palavra escolhida implica coisas e produz efeitos.

4 Regime de exceção que o governo de um país pode ditar em situações excepcionais. Palavra "emergência" refere-se à urgência ("situação de perigo ou desastre que exige ação imediata"), mas também ao que surge ou emerge, e que até então permanecia derrubado, como as pessoas sempre invisíveis que saíram às ruas em outubro para serem vistas, ouvidas, percebidas, notadas. (Veja https://www.eldesconcierto.cl/2019/11/02/delestado-de-emergencia-a-la-emergencia-ciudadana/Montealegre) 
antidemocrática como os golpistas em seguida decidiram impor "ordem" no país depois disso. Não é de estranhar que existam desenhos animados, riscos nas paredes e grafites que comparam os dois períodos ou, se não comparando, colocando lado a lado estes dois anos: "1973/2019".

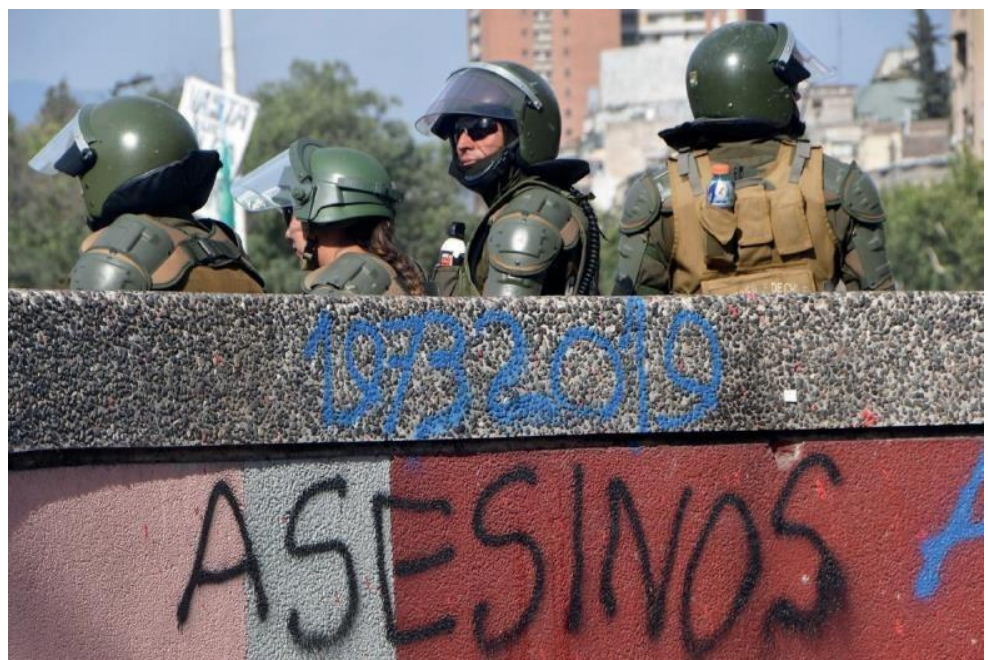

Figura 1 - Estação de Metrô Baquedano. Santiago, outubro de 2019. (Crédito: Yael Zaliasnik)

Nos tempos da ditadura cívico-militar, também foram evocados os números e o léxico da guerra. Falava-se sem parar sobre uma guerra. "Estamos em guerra entre o marxismo e a democracia", disse, por exemplo, Augusto Pinochet após sofrer uma tentativa de emboscada e assassinato em 1986 . Foi apontada a necessidade de erradicar a "invasão" comunista e/ou "terrorista", de "subversão". Algo semelhante disse o presidente do Chile, Sebastián Piñera, na noite de domingo, 20 de outubro de 2019, após um dia de fortes manifestações cidadãs e confrontos com a Polícia e os militares, quando expressou seu apoio ao trabalho das Forças Armadas e Carabineros. "Estamos em guerra contra um inimigo poderoso e implacável, que não respeita nada nem ninguém, que está disposto a usar a violência e o crime sem limites", disse ele à televisão nacional na segunda noite do toque de recolher em Santiago. Suas declarações, após reunião com o General Javier Iturriaga, nomeado Chefe da Defesa Nacional da Região Metropolitana durante o estado de emergência, foram duramente condenadas por seu tom bélico. 


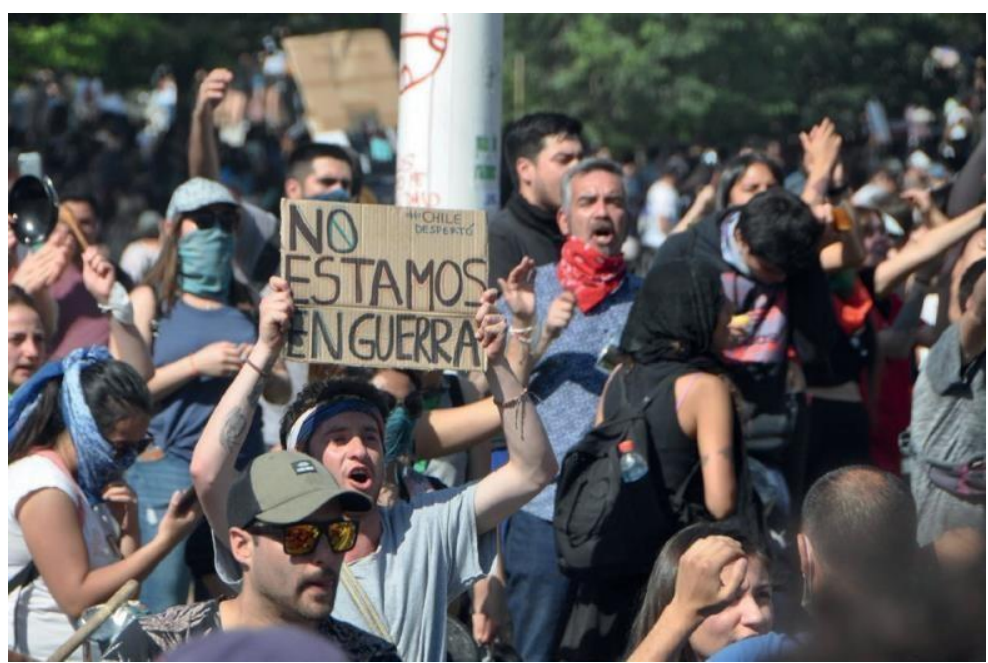

Figura 2 - Manifestação na Plaza de la Dignidad. Santiago, outubro de 2019. (Crédito:Yael Zaliasnik)

O próprio Iturriaga logo se distanciou deles, lembrando que "sou um homem feliz, não estou em guerra com ninguém".

$\mathrm{Na}$ verdade, Piñera havia usado essa frase (e/ou outras muito semelhantes) em várias circunstâncias e ocasiões anteriores: em 7 de abril de 2018 para a entrega de novas rádios patrulhas aos Carabineros; em 11 de junho de 2019, ao assinar o projeto de lei antiportonazos, quando afirmou que "nossa sociedade está em guerra contra o crime e o narcotráfico, e todos sabemos que esta é uma guerra dura e difícil, porque temos diante de nós um inimigo cruel, implacável e poderoso, que não respeita nada nem ninguém para atingir seus objetivos perversos" (LAWNER, 2020). Depois, no início da rebelião, e depois também. Em 28 de novembro de 2019, em meio a um aumento dos protestos, ele aproveitou a cerimônia de formatura de detetives para dizer que "estamos diante de um inimigo muito poderoso e implacável que não respeita nada nem ninguém". No dia 22 de fevereiro deste ano, após algumas manifestações em Valparaíso, ele reiterou que "estamos diante de um inimigo poderoso e implacável, que não respeita a vida dos seres humanos; que não respeita nossos heróis, como vimos com a degradação e ofensa à estátua de Arturo Prat".

Durante a rebelião popular, dizia-se e repetia-se que o "inimigo" era formado por criminosos. Também atribuíam às rebeliões uma possível ligação com o anarquismo, provavelmente devido à estigmatização dos que adotam essa ideologia, bem como alguns sinais nas ruas de Santiago, característicos desses grupos anti-establishment e antisistema. Esses eventos também foram organizados e incentivados do exterior. "Estrangeiro", palavra que, como aponta Herta Müller, é "tão neutra e, ao mesmo tempo, tão enviesada quanto o tom de cada voz ao pronunciá-la" (2011b, p. 24). Tudo foi colocado dentro dessa obsessão de culpar o "outro" pelo desacato, desordem, rebeldia, ficcionalização, sem querer ver o mais óbvio e real: que esse descontentamento estava presente há anos. "Não são 30 pesos, são 30 anos", a mensagem se espalhou por toda parte. 


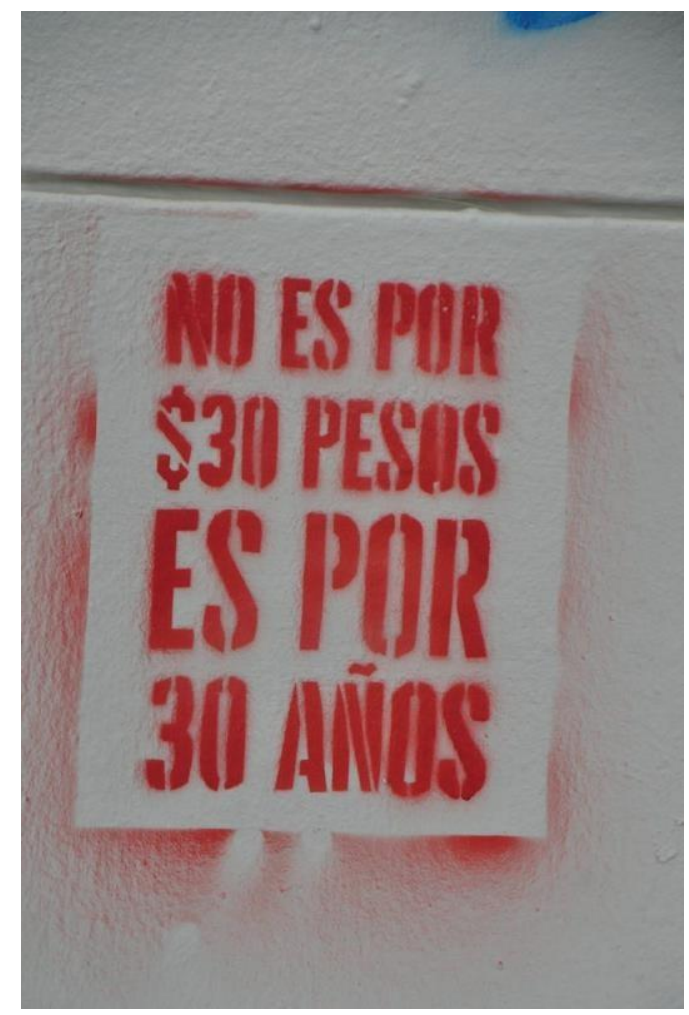

Figura 3 - Pintura na Av. Providencia. Santiago, novembro de 2019. (Crédito: Yael Zaliasnik)

Não se pretendia entender que a imagem lustrosa, brilhante e modelada do país era sustentada por uma enorme injustiça social, cultural, econômica e política, uma história cheia de abusos e até então e de certa forma naturalizada. E embora a "guerra" fosse uma declaração e uma percepção de poucos, o conceito e o ato de proclamá-la têm uma implicação política incontornável e, portanto, junto a ela, uma performatividade inegável. Como Clausewitz (2010, p. 23) apontou em seu texto clássico De la guerra, "todas as guerras devem ser consideradas como atos políticos." No mesmo texto, explica:

A guerra é uma mera continuação da política por outros meios. Assim, vemos que a guerra não é simplesmente um ato político, mas um verdadeiro instrumento político, uma continuação da atividade política, uma realização dela por outros meios. (CLAUSEWITZ, 2010, p. 22)

Assim também, o fato de recorrer à figura da guerra, as metáforas bélicas que surgem daqui e a própria guerra como metáfora têm em sua possibilidade de fazer coisas e de produzir afetos e efeitos (de ter eficiência performativa), uma politicidade inquestionável. Por esse motivo, não é de se estranhar que metáforas bélicas também tenham surgido no poder de resistência, como "Linha de Frente", nome apropriado por quem enfrentava os Carabineros todos os dias e que, com a pandemia, passou a ser usado para se referir aos trabalhadores da saúde que também "enfrentavam" todos os dias a Sars-Cov-2. Ainda assim, em janeiro de 2020, quando um grupo da chamada "Primeira Linha" foi ao 
Congresso, o então presidente da direita Renovação Nacional e atual ministro da Defesa, Mário Desbordes, expressou seu repúdio, ressaltando que as ações realizadas por essas pessoas estavam fora da lei: "não pode ser que esses anarquistas sejam homenageados no antigo Congresso Nacional" 5 . Assim, o "inimigo" foi identificado, caracterizado e ficcionalizado, e este, por sua vez, de alguma forma "pegou a luva", confrontando, organizando, carregando palavras e escudos, desligando e desativando o gás lacrimogêneo. Unindo-se. Cuidando. Muitos slogans vistos nas ruas naquela época mencionavam esse verbo em suas várias conjugações.

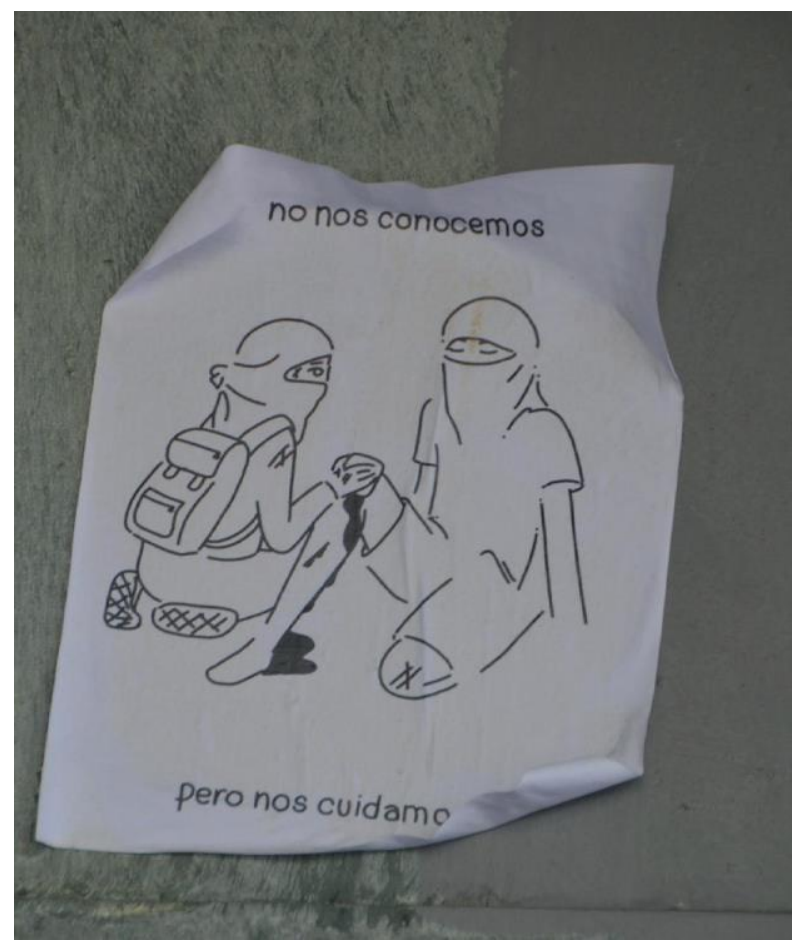

Figura 4 - Cartaz na Av. Providencia. Santiago, novembro de 2019. (Crédito: Yael Zaliasnik)

Durante a pandemia, aquela palavra - "cuidado" - voltou a ter importância e sua apropriação foi objeto de disputas. A desconfiança nas obscuras "estratégias" de um Estado que muitos suspeitavam que falava de "guerra" para justificar sua atribuição a uma necropolítica que visava assustar, passar por cima e até prender e/ou atacar aqueles que os perturbavam, incomodavam (a canção do grupo Los Prisioneros, "El baile de los que sobran" pôde ser ouvida em toda parte na rebelião). O mesmo Estado não resolveu as necessidades específicas de sua população durante a pandemia, ao mesmo tempo que nos culpava pelos fracassos e mortes, citando a falta de "autocuidado". Assim, aquele Estado que supostamente deveria nos proteger do "inimigo" conseguiu, sem querer, unir

5 O mesmo Desbordes quando deixou a presidência do Partido Renovación Nacional (RN) e o cargo de deputado no Congresso para se tornar Ministro da Defesa afirmou: "voltaremos à linha de frente na política". Em https://www. pauta.cl/politica/la-despedida-de-desbordes-volveremos-a-la-primera-linea-politica. No EMOL, em 29 de julho de 2020, foi intitulado "A saída surpresa de Desbordes da 'linha de frente' e sua chegada na Defesa que esfria a com Allamand". https://www.emol.com/noticias/Nacional/2020/07/29/993349/Desbordes-Ilega-a-Defensa.html 
tantas pessoas que, assim como durante a rebelião popular de 2019, compreendeu a força da organização e os laços da comunidade para lutar contra a adversidade da escassez de recursos econômicos e alimentares (e do abandono estatal) para sobreviver a cada dia (a possível "doença" de corpos dentro de um sistema também percebido como "doente"). Organizações populares que haviam atuado em outras crises, como as "ollas comunes" (cozinhas sociais) que se espalharam por todo o país, voltaram a agir, dadas as evidentes necessidades de grandes setores da população. Judith Butler se referirá ao surgimento nesses momentos de "comunidades solidárias" 6 como "um conceito que abrange famílias, estados, regiões e até mesmo nações. São tipos de comunidade que buscam oferecer saúde, transporte, informação médica, alimentação, direitos, entre outras coisas". E adiciona:

\begin{abstract}
Existem caminhos importantes para a mobilização política que surgiram dessas situações terríveis, e um deles é o das comunidades solidárias, que acredito poder se expandir em um movimento global e transregional que envolva o cuidado das comunidades. Isso implica distribuição de alimentos, distribuição de medicamentos, levar as pessoas ao médico, mas também formas de conhecer os próprios direitos, formas de saber como é ser tratado com dignidade, e uma certa ideia de que as minorias têm o direito de viver, elas têm o direito a condições sociais e econômicas que Ihes permitam continuar vivendo. (BUTLER, 2006) (tradução livre)
\end{abstract}

Apesar dos estereótipos criados, imaginados, percebidos e propagados por muitos, um número significativo de pessoas que saíram às ruas em outubro no Chile agora organiza várias atividades para apoiar a população mais precarizada. Da mesma forma, o contingente que enfrentou os Carabineros todos os dias na Plaza de la Dignidad foi e é incrivelmente heterogêneo, quebrando a estigmatização e ficcionalização que o poder de dominação tentou fazer dele. Este poder afirmava que o movimento era altamente organizado, vinculando-o a grupos anarquistas, conspirações internacionais e estrangeiras, das quais teria supostamente recebido materiais e instruções. Da mesma forma, em certas fases da pandemia, foram feitas tentativas de criminalizar, controlar e até perseguir aqueles que participavam da organização de "ollas comunes" (cozinhas comunitárias), implementando um protocolo administrado pelos Carabineros, visto por muitos como uma forma de coletar dados das organizações de bairro e obter maior controle social.

\title{
Mais sobre o inimigo
}

Sobre a rebelião, dizia-se que o suposto inimigo era poderoso, forte, "implacável", como destacaria Piñera. Porém, até o momento, poucos são os indiciados, por exemplo, pelo incêndio das estações do metrô de Santiago, pessoas claramente afastadas dessa descrição estigmatizada. O principal, um

\footnotetext{
6 No seminário "Estado de excepción-excepción del Estado. Conversaciones en torno al estallido social y la pandemia", organizado pelo Centro de Estudos de Ética Aplicada da Universidade do Chile. Em http://www.filosofia. uchile.cl/noticias/166129/judith-butler-las-comunidades-de-cuidado-pueden-expandirse.
} 
professor universitário de matemática que foi filmado quebrando uma catraca do metrô. Ou seja, tudo aponta para um grande desconhecimento do "inimigo" (usando o léxico imposto pelo Governo), o que é complicado em qualquer "guerra". Assim argumentou Sun Tzu, um autor anterior a Clausewitz, conhecido mais tarde no Ocidente. Em $A$ arte da Guerra, escrito entre os séculos VI e V a.C., na China, aconselha: "se você conhece o inimigo e conhece a si mesmo, não precisa temer o resultado de cem batalhas." (TZU, 2010, p. 35). Por outro lado, se você não conhece o inimigo, você só conhece a si mesmo, as chances de vitória ou derrota são semelhantes; e "se você não conhece nem o inimigo nem a si mesmo, perderá todas as batalhas." (TZU, 2010, p. 36). Isso é óbvio pela falta de consistência nas estratégias de "combate" à pandemia (também em nível global, embora alguns governos tenham sido menos erráticos). Quando o ministro da Saúde, Jaime Mañalich, disse desconhecer a aglomeração em que vive grande parte da população nacional, mas insistiu igualmente no plano "fondéate para el 18", em que até cinco pessoas que não morassem juntas em uma casa poderiam reunir-se com seus moradores, era ainda mais evidente o desconhecimento das próprias "tropas" e/ou "inimigos", conforme a conveniência.

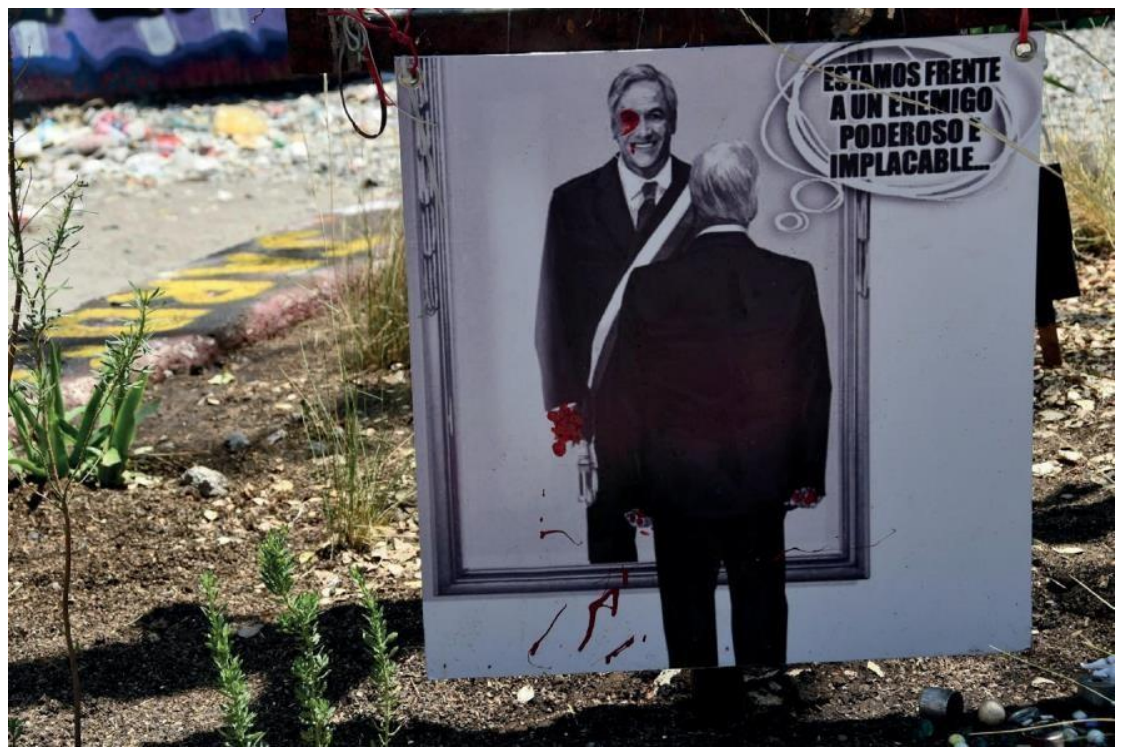

Figura 5 - Estação de Metrô Baquedano. Santiago, novembro de 2019. (Crédito: Yael Zaliasnik)

A abordagem bélica serviu de argumento para o governo reagir com raiva para tentar "controlar" a rebelião, prendendo os manifestantes", fazendo queixas jurídicas excessivas ${ }^{8}$, tentando tipificar (para proibir) novas atitudes, como uso de máscaras e barricadas, tentando puni-los, primeiro com violência policial excessiva e depois transformando-os em "prisioneiros", com penas altas e exageradas. "A guerra é um ato de força e não há limite para sua aplicação", diz Clausewitz, e foi assim que muitos oficiais do governo reagiram. O prefeito de

\footnotetext{
7 Cerca de 2.500 pessoas permanecem nas prisões chilenas presas durante a rebelião/protesto/"explosão", correndo o risco de longas e duras penas "instrutivas".

${ }^{8}$ Por exemplo, hoje um jovem acusado de jogar coquetéis molotov durante as manifestações está sendo sentenciado a 20 anos de prisão - inicialmente a sentença era 24 anos.
} 
Santiago, durante a rebelião, também iniciou a tentativa de "tática" ${ }^{9}$ de "tomada efetiva" da área onde está situada a renomeada Plaza de la Dignidad, completamente "sitiada" pelos Carabineros, em Santiago, chamada de "Zona Zero", área pela qual, como em qualquer guerra, havia "disputas" diárias. Durante a pandemia, foi reprimido quem se atreveu a sair às ruas para expressar o fato simples, sensível e terrível que resumido por uma palavra tão enfática, incômoda e desesperada como "fome". Também quando as comunas começaram a sair da quarentena, em meio a uma pandemia, era necessário o tempo todo ter "cuidado" com contingentes policiais na Plaza de la Dignidad, tentando manter o espaço apenas com os Carabineros e com as estátuas e muros imaculados. Várias vezes, manifestantes "detidos" na praça acusaram a polícia de, além de agredi-los fisicamente, obrigá-los a retirar as máscaras de proteção, juntando muitas pessoas em espaços muito pequenos, seja dentro de vans da polícia ou delegacias para onde foram transferidas. A referida estratégia evidencia a hierarquia dos "inimigos" do ponto de vista do poder de dominação e a quem se pretende de fato "proteger" e a quem não. E junto com isso, uma estratégia (nem tanto) oculta do necropoder de punir esse "inimigo", "prendêlo", transformá-lo em "prisioneiro", processando-o, condenando-o e até mesmo colocando em risco sua saúde, com a possibilidade de se infectar, espalhar o vírus e até morrer ${ }^{10}$.

Também chamamos atenção à palavra "detido", uma palavra com tantas conotações, um engrama de tantas memórias. "Detidos" pelos militares durante a ditadura, muitos foram torturados, executados e feitos desaparecer, acrescentando o apelido nefasto: "desaparecido", legado traiçoeiro daquela ditadura (com vários casos na nossa estranha pseudo-democracia), a bagagem vergonhosa e pouco apresentável de tantos países do nosso continente. Mas "detido" também tem a ver com o tempo em suspensão, com a espera, difícil para a maioria, habituada a um ritmo acelerado, onde a espera é geralmente vista como uma "perda de tempo". Por outro lado, fazer esperar foi durante muito tempo privilégio dos poderosos, que hoje também devem exercer sua capacidade de esperar. A pandemia então nos força a parar, a nos refugiar em nossas casas. E o confinamento evoca outro medo já vivenciado, quando, durante o "toque de recolher", os sons externos nos faziam temer pelo que estava acontecendo e/ou aconteceria. Um terror diferente, mas que nos tem despertado nos dias de hoje, evidência inegável de sua presença escondida, confusa. O medo como um continuum. O necropoder como um continuum. A ameaça à vida, à nossa vida. No passado. No presente. Também no futuro.

Toda guerra é disputa por um território, geográfico e/ou metafórico. Durante a rebelião popular, houve alguns locais "apropriados" pelos manifestantes, como muitas praças por todo o país, onde geralmente aconteciam

\footnotetext{
${ }^{9}$ Segundo Clausewitz, "a tática constitui o ensino do uso das forças armadas nos confrontos, e a estratégia, o do uso dos confrontos para atingir o objetivo da guerra, 2010, pp. 74-5)

10 Dada a superlotação e as condições precárias de higiene, nas prisões nacionais (como em outros países), a Sars-Cov-2 se espalhou muito mais do que na população chilena média, embora as informações não tenham sido muito transparentes. Ver: https://www.elmostrador.cl/destacado/2020/06/26/la-realidad-de-las-carce-les-enpandemia-y-la-falta-de-informacion-publica
} 
as manifestações geralmente espontâneas. Foi o caso, em Santiago, da Plaza de la Dignidad, mas também de outras, como a Plaza Ñuñoa e certas ruas onde, através de diversos atos - bicicletadas, shows, piqueniques, conselhos - onde se reuniam para falar, curtir, discutir, sentir-se sujeitos participantes de um período. A Plaza de la Dignidad, assim como praças em outras regiões, algumas rebatizadas com o mesmo nome, foi e é um cenário importante (não necessariamente bélico, mas ainda um cenário) durante a rebelião. Para significar, ressignificar, manifestar-se, proteger, apropriar-se, tentar "conquistála", "capturá-la" e até nomeá-la. "Dignidade" é outra palavra importante. Categórica, sublime e central nessas e outras "batalhas", em quase todos os aspectos da condição humana. Entretanto, aqui a communitas da esperança, unida pela razão e pela afetividade, agiu com mais rapidez e eficácia do que o poder de dominação; por isso nunca houve dúvida de que esta palavra pertencia a quem, desde 18 de outubro, saiu às ruas de todas as cidades do território nacional com o lema "até que a dignidade se torne habitual", entre outras coisas. Essa apropriação implicava o mesmo substantivo aplicado a um determinado espaço, um lugar praticado, na concepção de Michel De Certeau, por meio de diferentes atividades e assim os manifestantes ocuparam-no e se apropriaram desse espaço, renomeando-o entre eles. Com um termo único e nobre, que inclui em si o motivo de uma rebelião: recuperar a possibilidade de uma vida digna. (DE CERTEAU, 1996, p. 229)

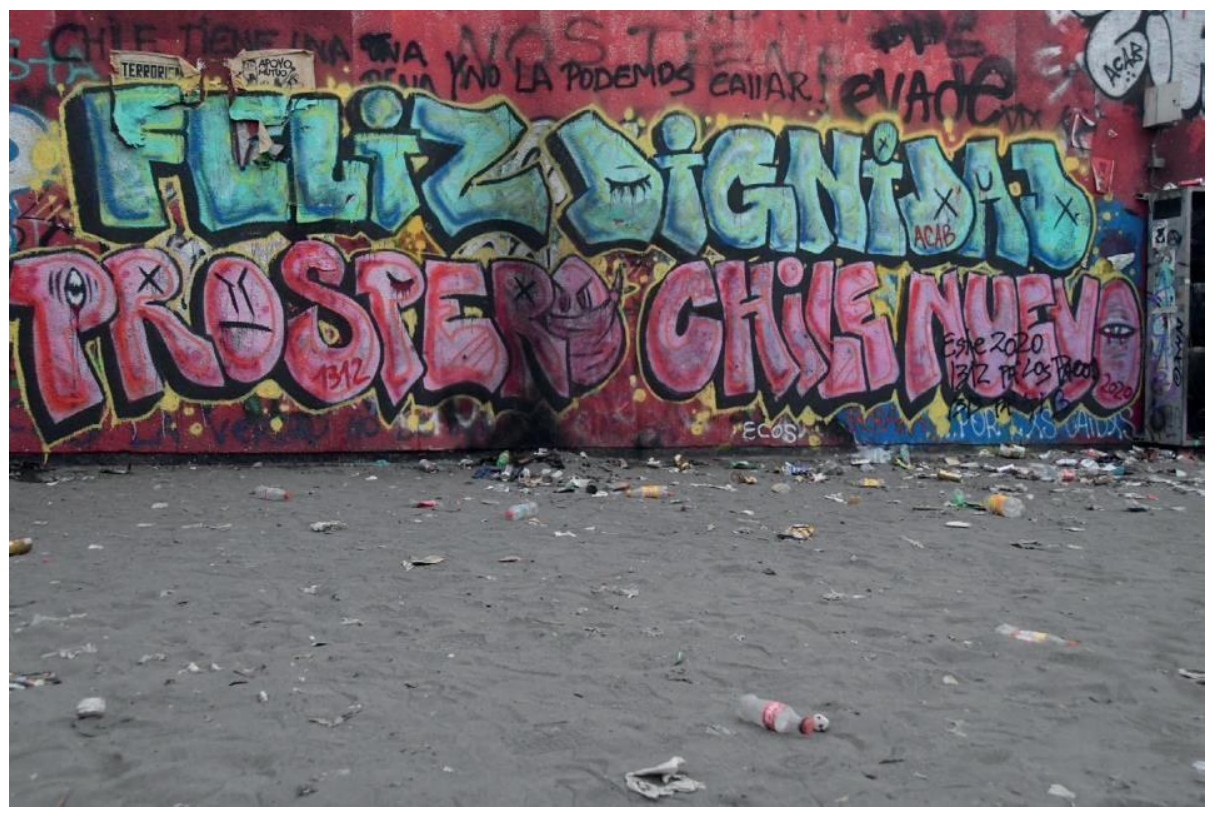

Figura 6 - Estação de Metrô Baquedano. Santiago, dezembro de 2019. (Crédito: Yael Zaliasnik)

Encenação da luta por territórios tangíveis, a partir do dia 18 de outubro, foram os confrontos todas as sextas-feiras entre policiais e manifestantes. Como num jogo, mas com chumbo grosso e feridas reais, com gases tóxicos venenosos, com abusos simbólicos mas também físicos (várias pessoas foram atacadas e atropeladas por carros da polícia, incluindo duas que foram atiradas 
ao rio Mapocho), os manifestantes voltaram repetidas vezes para ocupar a praça, colocando suas bandeiras, gritando seus slogans, obrigando a polícia a se retirar daquele território "sitiado". Território cuja apropriação ou "reconquista", bem como a sua "renomeação", foram um símbolo da recuperação da "dignidade" para um povo cansado de tantas injustiças e abusos.

O simbolismo da "conquista" do dito território - "conquista ": a ação de "ganhar ", através de uma disputa, um território, população, posição; mas, da mesma forma, a coisa que se conquista e a "conquista" de um amor é observado também em outro fato visto como excessivamente lamentável por muitos olhos $^{11}$. O fato de Piñera aproveitar o vazio da Plaza de la Dignidad em meio a uma pandemia, com Santiago em quarentena, para tirar uma foto no local e depois postar orgulhosamente sua foto deprimente nas redes sociais mostra a importância do território e suas mensagens e simbolismos. Todos os esforços feitos também durante a pandemia para, entre outras coisas, apagar graffiti, mensagens, reabrir estações de metrô, consertar semáforos, "apontaram" para essas mesmas mensagens.

Embora a rebelião que vinha ocorrendo desde outubro estivesse em certo estado de suspensão após o início da crise de saúde, ouvimos falar novamente sobre guerra, batalhas, inimigo (ou nunca deixamos de fazê-lo): o território metafórico da linguagem, a luta também pela sua "conquista". A medida de Piñera de decretar um "estado de catástrofe", e com isso impor um "toque de recolher," também coincidiu. Desta vez para supostamente nos proteger contra um inimigo que, além de ser "poderoso e implacável", era evidentemente invisível, embora o "inimigo" original também tivesse essas características. Isso tornou questionável a aplicação de certas ferramentas - "estratégias" ou "táticas", na lógica da guerra - que têm mais a ver com militarização, segurança e defesa nacional do que com segurança sanitária e saúde pública. Essas palavras agora eram usadas para falar da Sars-Cov-2, da necessidade de deter seu avanço, de desenvolver estratégias, de travar diferentes batalhas. No entanto era usada, principalmente, buscando mudar a ficcionalização de ambos os lados, tentando unir de um lado o inimigo da rebelião com seu oponente com os outros partidários - o então poder de dominação com o de resistência; tentando uni-los para agora enfrentar todos juntos este outro "inimigo" ainda mais poderoso que, conforme o tempo ia passando, atacava a todos igualmente, mas era muito mais danoso e letal quando atingia a população mais vulnerável e vulnerabilizada, de modo que aquela "união" que supostamente nos igualava se mostrava inexistente.

Procurou-se continuar na lógica bélica, sem reconhecer o erro da sua primeira aplicação, manipulando-a insistentemente para continuar a usá-la, consertando, sim, o erro não reconhecido de procurar separar e dividir a população em "inimigos" (ou que o inimigo era o povo). Mais uma vez,

11 "Olhos": Outra palavra que adquiriu uma carga significativa durante a rebelião, infelizmente, não apenas como uma metáfora do Chile que "acordou" e que não quer deixar de ver, após o ataque dirigido contra a visão dos manifestantes, que, por sua vez, falavam e realizavam atos para tornar visível o que, até aquele momento, foi deixado de fora de qualquer campo visual. 
procuravam um "outro" para culpar e enfrentar, mas desta vez para que todos nos uníssemos contra ele e não contra o Governo, os empresários, os abusos. Em abril deste ano, Piñera destacou que "o coronavírus é um inimigo poderoso e cruel que não respeita ninguém, especialmente para os pacientes do grupo de risco"12. Repetidas vezes, falava-se da necessidade de enfrentarmos este inimigo comum unidos, o que nos levava, mais uma vez, a esquecer o passado, especialmente as ações rebeldes, para enfrentar melhor - e supostamente juntos - esse novo e perigoso inimigo, como estratégia de triunfo para a primeira das "guerras" já mencionadas. "A guerra é o território do acaso", argumenta Clausewitz.

Depois de tomar conhecimento da magnitude da pandemia, com aumento iminente da curva de contágio, leitos ocupados, falta de respiradores, Mañalich disse que "foi declarada uma espécie de guerra por respiradores mecânicos". Em outra declaração, ele acrescentou "de grandes potências". No dia seguinte afirmou ainda que "estamos numa guerra por recursos para a saúde", dada a falta de respiradores em todo o mundo. Em maio, quando se constatou que as "estratégias" do Governo não contribuíam com o achatamento da curva das infecções pelo vírus, especialmente em Santiago, o Ministro da Saúde falou sobre "batalha de Santiago"13 e afirmava que "se não levarmos a sério a 'batalha de Santiago' com toda a energia, a guerra contra a COVID estará perdida", insistindo na união e que, pelo menos no discurso oral, as medidas de quarentena sejam respeitadas (NEIRA, 2020).

Em sua constante lógica e retórica de guerra, Piñera, que em tempos de rebelião popular alcançou uma aprovação de $4,6 \%{ }^{14}$, como um tirano solitário, narcisista e patético, realizaria o referido ato na Plaza de la Dignidad, para encenar sua questionável vitória. Porque, como assinala Clausewitz, se "a guerra constitui um ato de força que se realiza para obrigar o adversário a cumprir a nossa vontade", o suposto triunfo da primeira etapa da sua chamada "guerra", ou da primeira das duas últimas "guerras" declaradas pelo próprio Piñera, foi marcada pelo medo da pandemia que fez o povo - "o inimigo" - se retirar "recuar" - das ruas. Principalmente em Santiago, nos arredores da famosa praça. Naquele momento, Piñera aproveitou para tirar uma foto em uma Plaza de la Dignidad vazia, embora com pichações contra ele.

Tudo isso acreditando ou querendo acreditar na dimensão e na metáfora

\footnotetext{
12 A caracterização do vírus como "inimigo" não é tão nova, algo semelhante aconteceu com outras "pragas" na história da humanidade. Assim, em Um diário do ano da peste, de 1722, Daniel Defoe, a partir de seu personagem John, diante de uma discussão com moradores de uma cidade que, por medo de adoecer, tentam impedir a entrada de qualquer "estrangeiro", mandando que ele e seus companheiros retornem a Londres, ele diz: "o que nos impede de fazer isso é um inimigo ainda mais poderoso que você..." (DEFOE, 2010, p. 186).

${ }^{13}$ Outra infeliz escolha de palavras, porque na noite de 2 de abril de 1957, durante o governo de Carlos Ibáñez del Campo, durante uma onda de protestos nacionais de estudantes de secundaristas e universitários contra o aumento das tarifas de transporte público, o chefe da Guarnición de Santiago leu um "relatório de guerra" sobre o que chamou de "Batalha de Santiago" na rede nacional de rádio. Lá foram relatadas as "baixas" e feridos do "inimigo", fato que o historiador Iván Ljubetic descreve como um dos 55 massacres perpetrados no século XX. (Ver

http://puntofinal.cl/564/batallasantiago.htm?fbclid=IwAR3jonRRPrIAGg8xIcetZNZ3FpGFpnmo8gUx1PL5SRvCFv_ UXXo-1LAlbuM0)

14 No início de dezembro de 2019, de acordo com a Encuesta Pulso Ciudadano, em: https://www.biobiochile.cl/noticias/na-cional/chile/2019/12/02/aprobacion-de-pinera-cae-a-minimos-historicossolo-46-valora-su-gestion-segun-pulso--ciudadano.shtml
} 
bélica, ilusória e irracional, na qual o inimigo foi "desarmado", ignorando o mais óbvio: que o suposto "inimigo" estava cuidando dos perigos da pandemia, para continuar a luta contra a desigualdade que a rebelião iniciada em outubro promoveu e que esta emergência social de saúde só tornou ainda mais evidente. Por exemplo, ficou evidente quando o vírus se espalhou para os bairros mais pobres, onde população vive aglomerada e em condições muito mais difícieis para manter distância, medidas básicas de higiene e quarentena, entre outros motivos, já que a maioria trabalha e vive "dia a dia", sem poupanças ou empregos estáveis. Lá a verdadeira "guerra", ou pelo menos o dilema vital, para muitos consistia em escolher entre morrer de fome ou correr o risco de morrer infectado pela Sars-Cov-2, com um sistema de saúde precário. Byung-Chul Han, em entrevista à Agência EFE, fez uma previsão para o pós-pandemia, recorrendo à metáfora da guerra: "A sobrevivência se tornará absoluta, como se estivéssemos em permanente estado de guerra" (HAN, 2020).

Embora a maioria dos principais meios de informação nacionais e o próprio Governo se referiam continuamente às suas "estratégias de defesa", à compra de respiradores mecânicos, ao aluguel de diferentes locais como lazaretos (ou o eufemismo mais contemporâneo: "residência de saúde"), mudando quarentenas e, inicialmente, por comunas, logo se percebeu que embora este "inimigo" pudesse infectar qualquer pessoa, como sempre neste país (e em muitos outros), sua evolução foi diferente quando consideramos o nível socioeconômico, as condições em que cada um vive ou pode viver, o acesso desigual a saúde, a exames, à possibilidade de efetivamente fazer quarentenas ou manter "distanciamento", e até mesmo de contar com água potável ${ }^{15}$. Assim, a própria crise mostrou, revelou, confirmou, afirmou, assinou, enfatizou, iluminou, ampliou as grandes injustiças que o povo chileno tem gritado nas ruas desde outubro.

As oportunidades de se tentar esquecer tudo isso para enfrentarmos juntos um inimigo comum, revelaram-se evidentemente como uma inviável e tenebrosa estratégia para seguir governando ou, pelo menos, "controlando", vencendo, aproveitando ou canalizando o fator do acaso, a primeira dessas "guerras". Tudo isso, sem manifestações, revoltas, dando força a um medo tremendo e justificado na população do contágio, da doença, da morte. Além disso, suspeitou-se de "estratégias" que, para afetar o mínimo possível os lucros de empregadores e empresários estavam dispostos a sacrificar, de alguma forma, a vida de alguns, aquelas vidas com valor desigual, como aponta Butler (2006, p. 49), em prol da economia e do mesmo sistema já naturalizado, embora diagnosticado como "doente" pelas pessoas nas ruas. O governo promoveu diversas medidas que possibilitaram aos trabalhadores sacar de seus próprios "fundos" para sobreviver. Políticas de Estado, por suas ações e omissões, de

15 Segundo o artigo de Nicolás Sepúlveda e Benjamín Miranda, publicado pela Ciper Chile, "em https://ciperchile. cl/2020/06/21/coronavirus-tasa-de-mortalidad-de-los-hospitales-publicos-metropolitanos-duplica-la-de-las-clinicas/, a taxa de mortalidade por Sars-Cov-2 em hospitais públicos é o dobro das clínicas privadas. O mesmo texto cita estudo publicado na revista. The Lancet o que determinou que Santiago é a cidade com maiores disparidades de expectativa de vida entre as pessoas de acordo com a comuna em que residem, entre seis grandes cidades latino-americanas. Uma mulher nascida em uma comuna no nordeste do país, com residentes de alta renda, pode viver até 17,7 anos a mais do que uma mulher nascida em uma comuna na parte oeste. No caso dos homens, a diferença pode ser de até 9 anos. 
alguma forma fechando os olhos - novamente os olhos - para a realidade, no que Mbembe chama de "máquina de guerra" (MBEMBE, 2006, p. 59), onde, Segundo o manifesto futurista de 1909, "A guerra é concebida como higiene do mundo" (citado em VIRILIO, 2001, p. 49).

As mortes na pandemia, a forma fria de notificá-las, a insistência em culpar a população pelo seu destino, a repetição de dados que enfatizavam que o falecido tinha comorbidades ou idade avançada, justificando, de alguma forma, "as formas contemporâneas de submissão da vida ao poder da morte" (MBEMBE, 2006, pp. 74-75), buscava por meio de ações e omissões uma normalização e até manipulação. Isso, por meio de confusas e variantes fórmulas de cálculo dos números, de culpar a população pela multiplicação de infeç̧ões, de justificar ou normalizar de alguma forma certas mortes, do que o mesmo autor chama de "mundos da morte", manipulando e ocultando cifras, mas também palavras. A linguagem como um vírus. Por exemplo, os números de "recuperados", que a cada dia eram listados juntamente com os dados de óbitos e infecções e incluíam - como foi revelado e mesmo justificado ao longo do tempo - aqueles que faleceram, pareciam apontar para isso, minimizar e naturalizar as mortes por Sars-Cov-2. Uma "estratégia" que buscava fazer com que as pessoas se infectassem apostando, primeiro, na polêmica "imunidade de rebanho", ou seja, quem se infectasse ficaria depois imune para continuar funcional, caso sobrevivesse, no ciclo de produção, trabalho, consumo e só "tratar" os doentes depois de (gravemente) infectados em vez de cuidar da saúde e evitar o contágio. O horror então de um "necropoder" que, embora indiretamente (ou nem tanto) culpa outros (um vírus, os cidadãos) por não saberem se cuidar, é reflexo de um Estado que não protege as vidas mais vulneráveis, sacrificando-as quando têm dificuldade para respirar.

"Respiração": palavra que nos chamou muita atenção nos últimos tempos. Na rebelião popular, os manifestantes foram atacados - e continuam sendo - com gases tóxicos que afeta(va)m a capacidade de respirar. Os moradores de alguns bairros próximos à Plaza de la Dignidad reclamam com frequência e até colocam cartazes em suas casas e ruas exigindo o direito de respirar. 


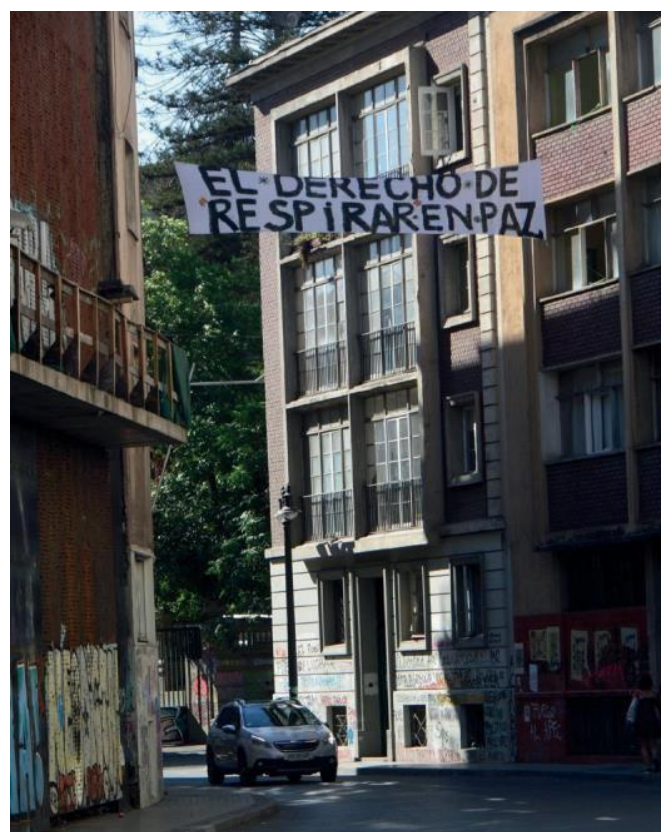

Figura 7 - Barrio Lastarria. Santiago, novembro de 2019. (Crédito: Yael Zaliasnik)

Hoje sabemos que alguns Carabineros praticaram manobras de asfixia sobre aqueles que ousaram se manifestar apesar da pandemia, alarmando e ameaçando secretamente a possibilidade de morte. A Sars-Cov-2, por sua vez, muitas vezes afeta a capacidade de respirar. Nessas "guerras" então, a respiração é uma parte importante das táticas e estratégias, bem como a mais contundente evidência de vida. Trazer nossa atenção para isso nos forçou a modificar um verbo e uma prática: outro verbo, outra prática. Modificar também, dessa forma, a evidência e o hábito natural de viver.

Isso tudo, junto com manipulações indiscutíveis. Assim como durante a rebelião se falava de anarquistas e estrangeiros, agora menos exames eram feitos, por exemplo, para reduzir os números ou os parâmetros eram alterados de acordo com o resultado desejado. Assim, em ambas as "guerras", enganar era um elemento essencial. Como Sun Tzu aponta, "toda a arte da guerra é baseada no engano" (TZU, 2020, p. 18).

Para além desta palavra, o seu uso e referência nos remete à ficção, a que sempre nos referíamos, visto que foi necessário ficcionalizar os roteiros das diferentes "guerras", das "tácticas", das "batalhas", das "armas", dos "inimigos" para que essa linguagem justifique, explique, crie, faça. Isso tudo anda de mãos dadas com a teatralização. Não porque algo não seja necessariamente verdadeiro, mas porque talvez possamos pensar sobre os elementos que ditos contextos/realidades/abordagens compartilham com o teatro e vê-los deste ponto de vista. Clausewitz, já em 1832, falava do "teatro de guerra" (CLAUSEWITZ, 2010, p. 59). No fundo, como Mbembe observou e enfatizou, há uma teatralização na hora de colocar e construir esses "cenários" de guerra. Aproveitando também as ideias de Mbembe, Ileana Diéguez, cunhou o conceito de "necroteatro", para se referir às teatralidades da morte, "performances que expõem mortes violentas como eventos de representação e produção de remessas de um necropoder" (DIÉGUEZ, 2016, p. 138). Embora ele desenvolva 
esse conceito para nomear os atos de violência tremendamente macabros e nefastos que ocorreram no México que intencionalmente buscam entregar mensagens por meio de sua "encenação", é possível aplicá-lo tanto nos atos de poder de dominação durante a rebelião (o ataque aos olhos, símbolo de inúmeras mutilações e ataques violentos fatais ou quase fatais contra os manifestantes) como na pandemia. Neste último fato, as mensagens são entregues de forma mais oculta e ambígua, principalmente pelo que não é dito, o que não é visto, o que não é mostrado. Pela mesma razão, desalojam e assustam. Pela ausência (ou vazio) de imagens, fruto do mesmo medo que levou ao confinamento, e pela ambiguidade.

Como vimos, ambas as "guerras" têm outros protagonistas e antagonistas. Para o Governo, na rebelião: a sociedade "civilizada" contra os vândalos/anarquistas que promovem a destruição e o caos; para os manifestantes: o povo contra o poder econômico e político oligárquico, que também atua reprimindo com seus "braços armados": a polícia e os militares. Na pandemia, o Governo tenta introduzir através do discurso a ideia de uma "guerra", que é "todo o Chile contra o Coronavírus", onde militares e policiais trocariam rapidamente de papel, para proteger e supostamente cuidar de toda a população. É claro que, como em tudo o que é humano, há também nas guerras (verdadeiras, não apenas metafóricas) uma importante dissociação entre as mensagens e os discursos veiculados pelos meios de comunicação, os boatos, os depoimentos de representantes institucionais e aqueles que se entregam através de ações concretas. "Se você quer saber no que homens e mulheres realmente acreditam, não preste atenção no que eles dizem, mas no que fazem" (tradução livre), destaca Terry Eagleton o que disse Karl Max (cit. In CAPARRÓS, 2014, p. 428). Na prática, nem todo Chile se ajusta tão rapidamente à mudança de "inimigo" e ao "reordenamento de forças". Muitos ficam ainda mais conscientes de que, em vez de tomar um lado, como na revolta, nem todos possuem as mesmas "armas", por isso continuam a se rebelar. De vez em quando, por exemplo, como resultado dos protestos durante a pandemia, parece ser evidente que a "guerra" anterior não só não acabou, mas que, pelo poder de dominação, ou pela mentalidade governamental, as mesmas pessoas continuam sendo os "inimigos". Os mesmos militares e policiais nas ruas, controlando a "ordem", o mesmo "toque de recolher", a mesma criminalização do protesto, os mesmos políticos e o mesmo governo, todos sem sinais de entendimento ou de querer mudar alguma coisa; o mesmo ataque aos ativistas sociais, a mesma lógica de "queixas", julgamentos e condenações contra aqueles que tentam expressar até mesmo suas necessidades, resumidas talvez na mais desesperada de todas as palavras: "fome".

Categórica. Porque, como aponta Caparrós, "a fome não é discutível. A fome é a expressão mais indiscutível da pobreza, o ponto em que cessa qualquer debate" (CAPARRÓS, 2014, p. 508). Seu grito assusta o Governo e seus defensores pela própria firmeza e porque basta retomar um pouco a história para confirmar que este tem sido o motivo de muitos levantes civis, de tantas revoluções. A fome é uma expressão óbvia de miséria, "condição em que, 
quando algo - qualquer coisa - falha, tudo desmorona. O equilíbrio tão precário" (CAPARRÓS, 2014, p. 468). Nesse estado de coisas, é sarcástico atribuir o alto número de infecções e mortes à irresponsabilidade de uma população que, em grande medida, não possui nem mesmo as coisas mais básicas para fazer uma quarentena ou sobreviver um único dia em qualquer contexto. Embora praticamente faltam imagens (não só filas em hospitais, funerais lamentosos e lugares públicos devastados pelo desamparo, fome, medo), a ausência de outras imagens é, sobretudo e neste caso, a representação deste necroteatro, dominado por um medo imenso e paralisante, muito difícil de mostrar iconograficamente e, portanto, imaginado e reimaginado de mil maneiras por aqueles de nós que carecem de referências visuais concretas ${ }^{16}$. O efeito ou entrega, neste caso, do necropoder foi e é por meios mais sutis, o boca a boca em que ouvi(a)mos dos enfermos e dos mortos próximos, as sirenes soando incessantemente, despertando, também, o nosso imaginação assustada e macabra e, em muitos casos, a experiência pessoal ou de alguém próximo que nos obrigou a sair à rua, a tentar conseguir uma vaga (ou informação) num hospital, a assistir a um funeral extremamente sombrio, vazio e amedrontador, a arriscar e temer um possível contágio, ignorar nossas próprias reações diante da propagação de um medo tão impalpável e excessivo.

Havia também a suspeita geral de que as medidas de abertura estivessem relacionadas a uma estratégia para adiar ou suspender o plebiscito de 25 de outubro (para decidir se mudaria ou não a Constituição de 1980, em vigor no Chile desde a ditadura), conquistada em uma "negociação" após a rebelião de outubro. Ficou evidente a percepção e consciência da população neste necropoder, tão associada à já referida palavra "engano", arma marcial por excelência. Acreditava-se que o governo e alguns políticos eram capazes de recorrer a uma estratégia de contágio, doença e morte para atingir seus fins políticos, assim como se suspeita que a ambiguidade das mensagens e políticas atuais correspondem a fins econômicos. Para além das intenções, as suspeitas frequentes indicam uma clara consciência da sua exequibilidade e a constante e profunda desconfiança dos cidadãos face às prioridades e palavras dos seus líderes.

\section{Outras palavras - "armas"/a(r)me-se}

Como em qualquer "cenário de guerra", os corpos são fundamentais. Os corpos vivos, ativos e desafiadores junto com os corpos "detidos", "presos", doentes, inertes. A rebelião convocou aqueles que vieram com seus corpos raivosos e provocadores, cansados de seus constantes maus-tratos, falta de oportunidades, desigualdade, injustiça com o espaço público, energizados pelo que o Subcomandante Marcos chamou de "a fúria digna". O mesmo espaço que, depois de alguns meses e devido à pandemia de Sars-Cov-2, tiveram que deixar

16 O efeito oposto certamente também é possível. Assim, duas mulheres apareceram em um vídeo que foi divulgado nas redes sociais. Recusaram-se a usar máscaras, como explicou uma delas, porque "tudo é mentira, não vi gente morta". Em https://www.eldesconcierto.cl/2020/09/24/video-mujer-niega-mascarillas-no-he--vistomuertos/ 
para se confinarem em suas casas. No entanto, em 18 de maio, 7 meses após 18 de outubro e com Santiago em quarentena, a raiva e as necessidades não atendidas levaram muitos moradores a sair às ruas para protestar. A fome e o desespero desencadeados por ele eram maiores que o medo da pandemia. Primeiro foi na comuna de El Bosque, e logo Villa Francia e La Pintana logo se juntaram.

Naquela mesma noite, o coletivo artístico Delight Lab projetou de baixo para cima em uma das paredes laterais do alto e icônico prédio da Telefónica, na Plaza de la Dignidad ${ }^{17}$, a triste, forte, assustadora palavra "fome" (mais do que a palavra, seu referente, ambos entrelaçados, misturados, duros, horríveis, rudes, temíveis, intransponíveis, inegáveis), a mesma que foi gritada pelos manifestantes de El Bosque e motivo evidente de vários saques naquela noite em alguns supermercados.

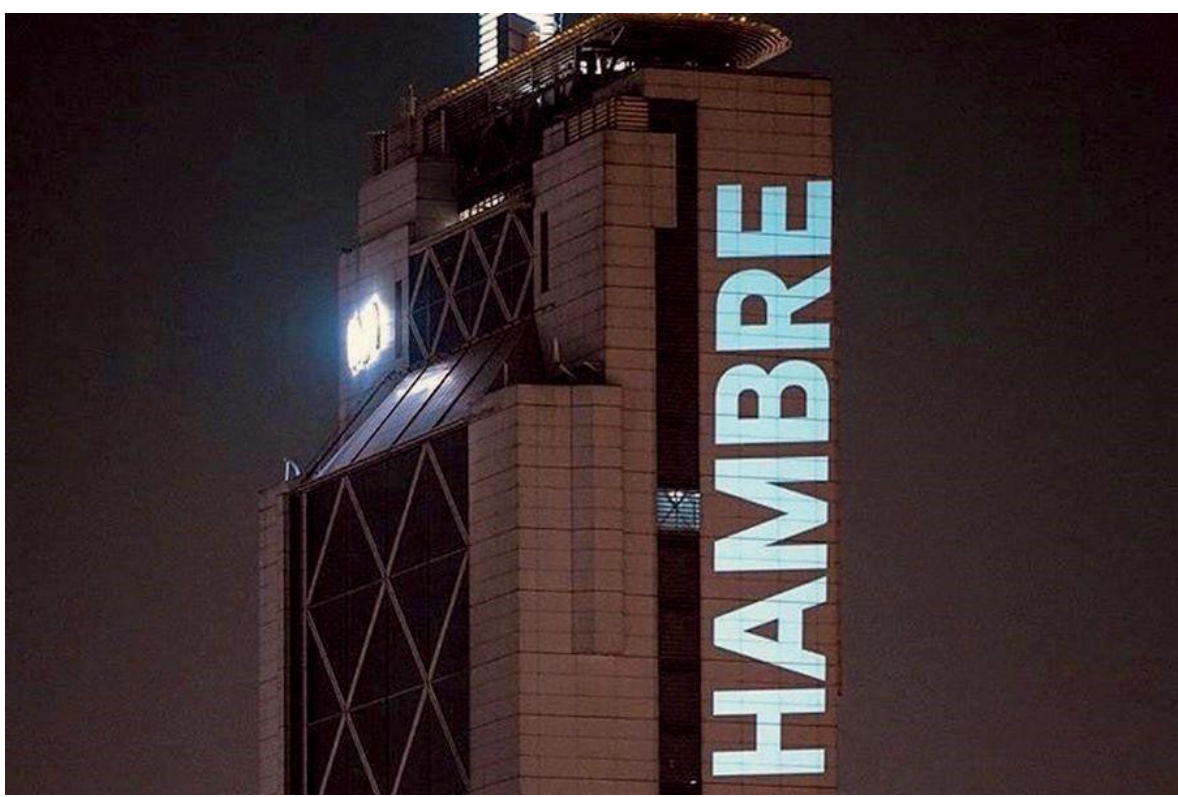

Figura 8 - - Edifício Telefónica. Santiago, 18 de maio de 2020. (Crédito: jornal La Tercera)

Dos muitos representantes da direita chilena, talvez a voz mais popular seja a do deputado da Renovação Nacional, Diego Schalper, que relacionou este protesto com a instalação de iluminação local, acusando de uma evidente organização na "encenação" dos eventos, orquestrada, segundo ele (e outros) pela "esquerda" para atacar o Governo, qualificando de "miseráveis" aqueles que os idealizaram e participaram, aparentemente sem saber que "miséria" e "fome" caminham inexoravel e tristemente de mãos dadas. Essa mesma palavra, "miserável", já vinha sendo disputada -especialmente através do Twitter entre representantes de diversos setores por alguns dias, uns para falar sobre as

17 Que contém uma mensagem importante, pois é a mesma direção em que a informação viaja vinda de uma população economicamente pobre da periferia de Santiago para pessoas claramente distantes não só fisicamente, mas também em conhecimento e empatia, o que pôde ser percebido pelos comentários de muitos, que acusaram partidos políticos de uma "montagem" planejada com "atores" que não representavam o tipo de pessoa que eles esperavam que gritaria essa palavra; ignoravam, inclusive, que a má nutrição não é necessariamente vista em corpos extremamente magros. 
estratégias do Governo diante da pandemia, e outros, sobre as críticas a elas. Todos com pressa de "vencer" também uma "batalha" retórica cada vez mais evidente, depois de alguns lamentarem ter chegado tarde, por exemplo, quando a bela palavra "dignidade" já havia sido apropriada pelo povo chileno.

Logo ameaças violentas chegariam ao Delight Lab, que as tornaram públicas por meio das redes sociais, principalmente depois das queixas do próprio senador Schalper sobre o grupo, levando a projeção de novas palavras. No dia seguinte da projeção da palavra "solidariedade" e depois "humanidade", um caminhão protegido por Carabineros apareceu na rua com potentes holofotes que visavam evitar essas e outras possíveis projeções de palavras ${ }^{18}$. 0 medo das palavras. Sua "batalha". Logo vimos através das redes sociais uma projeção no mesmo site mas com letras escuras na luz, da palavra "censura"19, sendo ainda mais evidente então, ao recorrer também ao léxico bélico, uma "guerra" que é também - e que ocupa um lugar muito importante - de palavras ${ }^{20}$. Guerra, cujas diferentes posições podem ser resumidas em um cartaz, assinado pelo coletivo Les comunes, afixado a partir de 18 de outubro em algumas paredes da Rua Providencia, onde se lê: "Á(r)mate" (a[r]me-se). A defesa contra a necropolítica (parte da "guerra" de alguns) se dá, protanto, por meio do cuidado, do afeto, da comunidade e do comunitário. Daí também as seguintes palavras projetadas: "solidariedade", "humanidade".

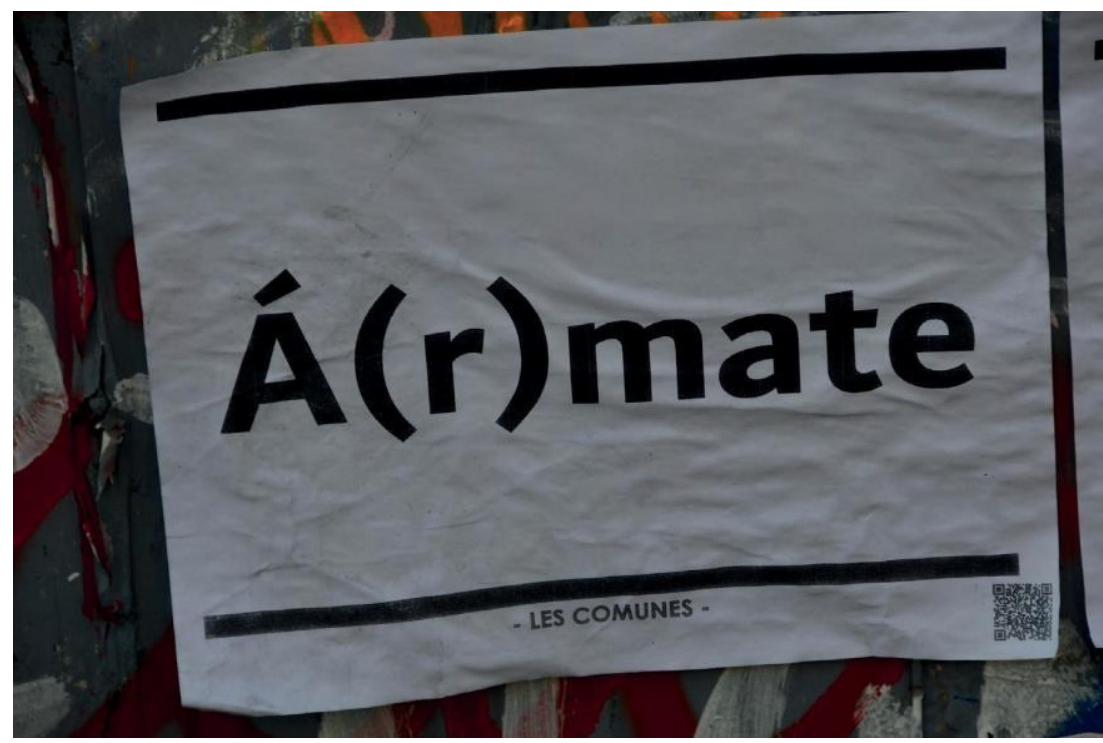

Figura 9 - Parede da Av. Providencia. Santiago, novembro de 2019. (Crédito: Yael Zaliasnik)

18 Da mesma forma, com as luzes de um carro de Carabineros tentaram "apagar" a mensagem circular em torno da estátua do General Baquedano no centro da praça projetada em 24 de setembro de 2020, com a frase: "Destruir em nossos corações a lógica do sistema" e, ao centro, com luzes azuis, a chamada Estrella de Arauco (Guñelve), símbolo tradicional mapuche. Tudo isso durante a Semana das Artes Visuais Barrio Arte, atividade apoiada pelo Ministério das Culturas.

${ }_{19}$ Diz-se que foi o produto de uma montagem fotográfica que também foi utilizada nas redes sociais para colocar outras mensagens nessa e em outras fachadas

$20 \mathrm{Na}$ segunda-feira, 24 de maio, de acordo com TheTimes.cl (https://thetimes.cl/internacional/en-chile-secensura-iluminan-torre-eiffel-tras-bloqueo-a-palabra-hambre-en-santiago.shtml?fbclid=IwAR3-

i9BvMJfOljoUTOe8Xtn87sJa1hW78i-cGj6tAexyHiYqRS4Ngz3m8L2c), la Torre Eiffel de París se iluminó con varios mensajes relativos al episodio ocurrido con Delight Lab y el bloqueo a sus proyecciones en la torre Telefónica de Santiago. Organizado pela organização Solidarité Chili France, as palavras "fome" e "no + censura" também foram projetadas no ícone francês 
Ficou evidente também o medo desencadeado por certas palavras e imagens que, como aquelas pichações surgidas após a rebelião, foram apagadas, mostrando grande temor e consciência sobre linguagem e sobre sua performatividade. E esta mensagem, que embora não seja marcada no espaço público, mas esteja no imaginário, em tempos de pandemia e toque de recolher, com pouca gente e protestos de rua, ganha força, pois impulsiona a imaginação e a criação de outros espaços e métodos de protesto em tempos de confinamento (para que ninguém "leia" a solidão e o silêncio enganoso de tempos de pandemia como vitórias marciais). Dessa forma, uma importante política da censura é mais uma vez evocada, que nos conecta com o que vivemos durante a ditadura.

Em carta a um jornal de circulação nacional, Felipe Cussen tornou pública a reivindicação da Lei da Transparência à Administração Metropolitana. Lá ele perguntou sobre seu envolvimento e responsabilidade na referida ação de censura. Em seu último ponto, questionou "se a Administração Metropolitana considera que 'humanidade' é uma palavra condenável e por quê", recorrendo ao sarcasmo para um pano de fundo irracional que transcende esses acontecimentos. Por meio deles, a projeção, reações, censura, as formas criativas e alternativas de evitar o silêncio (e sua comparação com o período ditatorial) são evidentes, mas também a performatividade da linguagem e a consciência e o medo que isso provoca. No caso da palavra "fome", ela está claramente desperta e mobiliza uma série de pensamentos e sensações; uma palavra que assusta um governo e seus seguidores, que, pelo mesmo motivo, procuram não ouvi-la ou divulgá-la.

Não em vão, muitos, senão todos, levantes e revoluções surgiram de uma população faminta. Em primeiro lugar e obviamente, a fome real e tangível, mas também a falta de muitos outros nutrientes, desejos, sonhos. Mais do que a palavra, a sua referência dura, uma realidade que muitos insistem em não querer ver e que, em diversos momentos, até foi designada como "peste". A peste também como uma metáfora ${ }^{21}$. Por isso, projetá-la no espaço público, ainda que de forma efêmera, na fachada de um edifício em um lugar simbólico do "despertar do Chile", como também é conhecido o movimento iniciado em outubro de 2019, moveu algo do que havia sido supostamente congelado com a pandemia. Assim se desencadearam ações e reações, em mais uma "batalha" desta "guerra". Engoliu e evidenciou, com a força performática de algumas palavras, a começar por "fome", a realidade perversa de uma sociedade indignada e frustrada, cujas diferenças e reivindicações se tornaram ainda mais evidentes após a crise social e sanitária.

Como hoje os números estão escondidos, as palavras são o centro da disputa, geram-se "guerras" de diferentes calibres e tipos. O que para alguns é

${ }^{21}$ A fome generalizada em alguns tempos e espaços foi catalogada como tal, por exemplo, pelos ucranianos, que chamaram de Holodomor - a praga da fome - ao que vivenciaram em seu país depois que Stalin declarou a coletivização da terra em 1929, que o os kulaks (camponeses proletários) eram inimigos de classe e deveriam desaparecer e que, em 1932, Moscou ordenou que os campos entregassem cotas de grãos, o que deixou a maioria sem nada para comer, passando fome, na primavera daquele ano, 25.000 pessoas (CAPARRÓS, 2014 , p. 211). 
motivo de riso, para outros é um reflexo da seriedade e da importância da disputa semântica e política que, é claro, caminham juntas. Assim, na "batalha" entre a "aprovação" e a "rejeição" de uma nova Constituição, em meio a uma pandemia, a campanha de "rejeição", liderada por muitos dirigentes de direita, quis recorrer à frase e nome de uma canção de Víctor Jara: "El derecho de vivir en paz", tema que tem sido mote e incentivo de muitos ideais, movimentos, manifestações. Foi uma constante, por exemplo, nas marchas e manifestações pela rebelião de outubro. Agora buscava-se descontextualizá-la e esvaziá-la de seu sentido original, tentando ressignificar e apropriar-se, a princípio, daquela palavra central e disputada desde a rebelião: "paz". De fato, buscou-se "Um Acordo pela Paz", panos brancos foram colocados na Plaza de la Dignidad e tentou-se divulgar uma canção feita para a ocasião que falava de "paz". Ele queria e quer entender, sim, "paz" como a ausência de qualquer conflito. Não porque não existam, mas porque se recusam a vê-los, percebê-los, aprofundálos, discuti-los, elaborá-los (para o qual queriam acreditar que a pandemia colaborou). Na verdade, esta questão foi criada por Jara para protestar contra a intervenção dos EUA no Vietnã, uma interferência que os Estados Unidos replicariam no Chile para apoiar o golpe de 1973, que trouxe consigo perseguição, tortura, assassinato e "desaparecimento" de milhares de Chilenos. Entre eles, o próprio Jara. Muitos daqueles que mais tarde chamaram para votar "rejeição" apoiaram essas ações para mais tarde não querer dizê-lasou notá-los em nome da "paz".

\section{A palavra "conclusão" também pode parecer muito categórica}

Além do apagamento do grafite, a trajetória de uso e percepção dos lenços/protetores faciais/máscaras, da rebelião à pandemia, principalmente pelo poder de dominação, de certa forma ilustra uma consciência crescente da possível performatividade da linguagem. Na primeira das "guerras" proclamadas por Piñera prevalecia a possibilidade desse objeto de cobrir o rosto, de esconder a identidade. Para o segundo, era mais importante evitar o alcance do espirro. No entanto, cobrir a boca implicava também na repressão da voz e das palavras que, portanto, eram muito mais difíceis de ouvir e comunicar. Um cartaz durante a rebelião popular afirmava: "só os beijos cobrirão nossas bocas." Mais uma vez, mostram-se os afetos contra a violência e a falta de sentido desta "guerra" autoproclamada pelo Governo. No entanto, essas estratégias não foram suficientes para alcançar a verdadeira "paz". Apenas aproximou-se da ideia já explícita de evitar conflitos, obstruindo os diferentes sentidos e, com eles, as memórias. Isso ficou evidente quando os moradores também saíram às ruas para protestar. A mesma ideia foi seguida da convocação de um panelaço - a forma mais comum de protesto durante a pandemia -, que dizia: "a máscara não é um focinho diante da fome e da miséria". Essa noção da máscara como instrumento sanitário, mas nunca como uma "focinheira" (espécie de "ortopedia" que "corrige" a temida e amplificada "voz"), foi amplamente repetida em diferentes convocações pelas redes sociais. Porque embora o olhar e a percepção 
do poder de dominação diante de dito objeto tenham se transformado, viu-se um certo benefício se fizermos a ligação com a ideia por trás de uma focinheira. No entanto, logo percebemos que as máscaras eram para cuidar de nós e dos outros. Volta ao centro, onde sempre deveria ter estado, a palavra "cuidado". Não se tratava, evidentemente, da gestão individual do atendimento a que as autoridades recorrem habitualmente para liberar o Governo de ter que lidar com a pandemia, nem se tratava de ficar calado, de deixar de nos expressar, de nos defender, de reclamar, de gritar. Podemos nos manifestar com sons, batendo em panelas; com palavras, exibindo mensagens em instalações de luz, nas redes sociais, em pontes e paredes. Mesmo com uma máscara, podemos nos expressar, gritar, protestar, encenar nossos vários atos de fala, que buscam não apenas reivindicar, gritar, falar, mas também fazer.

Como Austin colocou, uma teoria da comunicação que toma o campo da linguagem comum ou "linguagem ordinária" também pode nos esclarecer sobre a construção de significado em e por meio de nossos atos de fala, que não se relacionam apenas simbolicamente com nossas ações, mas também as constitui. Sua análise pode ser útil para revelar diferentes racionalidades que são dialogicamente postas em jogo em diferentes contextos históricos. Assim, a linguagem marcial da guerra e do inimigo, a busca da culpa, a lógica repressiva e suas repercussões nos diversos "cenários" nacionais (e globais) deixam claro que "palavras fazem coisas". O que fazem? O que causam? Que racionalidades colocam em jogo? Embora seu uso varie em cada contexto, como fica claro a partir da análise do uso da linguagem bélica em ambas as situações, a construção de "guerras" e "inimigos" está associada a profundas "trincheiras" metafóricas que procuram isolar, demonizar e até eliminar os "outros" ao invés de ouvi-los, culpando-os por sua própria ineficiência. Em uma guerra, todas as leis sociais são abolidas e tudo é possível em seu nome para manter o controle pela força, atacar, violar, matar. Também tenta apelar e estimular o medo da população para alcançar, através da necropolítica, um controle rígido da comunidade e, assim, tanto em tempos de rebelião quanto de pandemia, garantir que tudo permaneça igual (que haja "paz", em seu significado mais controverso, brando e asséptico). No entanto, isto está gerando na força da resistência um sentimento de unidade e comunidade diante do que para muitos é o verdadeiro inimigo "poderoso", "implacável", "que não respeita nada nem ninguém" e "disposto a usar a violência sem limites". Violência frequentemente exercida também por meio de palavras. Declarar guerra, inventar um inimigo, ocupar a praça, batizá-la, proibir ações diversas, são todos verbos que criam realidades; o mesmo acontece com a escolha e disputa deliberada de certas palavras, o que leva Mário Benedetti a perguntar/sugerir/exigir em seu poema "As palavras"

(...)Não desperdice minhas

palavras

Não mude o significado

Veja o que eu quero

Tenho isso bem claro 
Se você fala de paz mas

tem

Costume de torturar

Veja que para esse vício

Há uma cura radical (...)

\section{Referências}

AUSTIN, John Langshaw. Cómo hacer cosas con palabras. Trad. Genaro Carrió y Eduardo Rabossi. Ciudad de México: Paidós, 2018. 219 p. ISBN: 978-607-747-578-1

BHABHA, Homi. El lugar de la cultura. Trad. César Aira. Buenos Aires: Manantial, 2007. 308 p. ISBN: 978-987-500-074-2

BUTLER, Judith. Vida precaria: el poder, el duelo y la violencia. Trad. Fermín Rodríguez. Buenos Aires: Paidós, 2006. 151 p. ISBN: 950-12-6557-9

CAPARRÓS, Martín. El hambre. Buenos Aires: Planeta, 2014. 610 p. ISBN: 978-95049-4053-1

CLAUSEWITZ, Karl von. De la guerra. Disponible en <https://www.biblioteca.org.ar/ libros/153741.pdf>

DE CERTEAU, Michel. La invención de lo cotidiano 1. Artes de hacer. Trad. De Alejandro Pescador. México: Universidad Iberoamericana, 1996. 229 p. ISBN: 968-859-253-6

DEFOE, Daniel. Diario del año de la peste. Trad. Pablo Grossmichd. Valencia: Impedimenta, 2010. 322 p. ISBN: 978-84-937601-8-2

DIÉGUEZ, Ileana. Cuerpos sin duelo. Monterrey: Universidad Autónoma de Nueva León, 2016. 437 p. ISBN 978-607-27-0518-0

"General Iturriaga: 'Soy un hombre feliz, no estoy en guerra con nadie'", CNNChile.com. 21/10/2019. Disponible en:<https://www.cnnchile.com/pais/general-iturriaga-soy-un-hombre-feliz-no-estoy-en-guerra-con-nadie_20191021/>. Acceso 23 de agosto, 2019.

HAN, Byung-Chul. "Viviremos como en un estado de guerra permanente". Entrevista con Isabela Gresser. Disponible en <https://www.efe.com/efe/espana/destacada/byung-chul-han-viviremos-como-en-un-estado-de-guerra-permanente/10011-4244280>. Acceso 12 septiembre, 2020.

LAWNER, Miguel. "Piñera Otra Vez: 'Estamos enfrentando a un enemigo cruel y poderoso" ". El clarín.cl. 17 de abril, 2020. Disponible en https://www.elclarin. cl/2020/04/17/pinera-estamos-enfrentando-a-un-enemigo-cruel-y-poderoso/ 
MAILLARD, Chantal. "La herida en la lengua". En un principio era el hambre. Antología esencial 1990-2015. Madrid: Fondo de Cultura Económica, 2015. 176 p. ISBN: 978-84-375-0730-9

MBEMBE, Achille. Necropolítica. Trad. y edición Elisabeth Falomir. Madrid: Melusina, 2006. 120 p. ISBN: 978-8496614-19-2

"Ministro Mañalich: 'El enemigo es uno solo y se llama coronavirus' ". En <HTTPS:// RADIO.UCHILE.CL/TEMAS/COVID-19/>. Acceso 22 de agosto, 2020.

"Ministro Mañalich: 'Nuestro único enemigo es el coronavirus' ". Audio en Cooperativa.cl, 2 de mayo de 2020. Disponible en <https://www.cooperativa.cl/noticias/ sociedad/salud/coronavirus/ministro-manalich-nuestro-unico-enemigo-es-el-coronavirus/2020-05-02/124742.html>. Acceso 24 de agosto, 2020.

MÜLLER, Herta. El rey se inclina y mata. Trad. Isabel García Adánez. Madrid: Siruela, 2011a. 190 p. ISBN: 978-84-9841-428-8

MÜLLER, Herta. Hambre y seda. Trad. Isabel García Adánez. Madrid: Siruela, 2011b. 186 p. ISBN: $978-84-9841-619-0$

NEIRA, Cristian. "Mañalich declara 'la batalla de Santiago' al 'enemigo portentoso' coronavirus y acusa irresponsabilidad de capitalinos". El desconcierto.cl, 3 de mayo de 2020. Disponible en <https://www.eldesconcierto.cl/2020/05/03/manalich-declara-la-batalla-de-santiago-al-enemigo-portentoso-del-coronavirus-y-acusa-irresponsabilidad-de-la-gente/>. Acceso 22 de agosto, 2020.

SUBCOMANDANTE INSURGENTE MARCOS. El dolor y la rabia. Comunicado del Ejército Zapatista de Liberación Nacional, México. (2014, mayo 8). Enlace Zapatista. Recuperado de: http://enlacezapatista.ezln.org.mx/2014/05/09/el-dolor-y-la-rabia/

TZU, Sun. El arte de la guerra. Trad. Benjamín Briggent. Madrid: Plutón Ediciones, 2010. 126 p. ISBN: 978-84938061-5-6.

VIRILIO, Paul. El procedimiento silencio. Con introducción de Andrea Giunta. Trad. De Jorge Fondebrider. Buenos Aires: Paidós, 2001. 112 p. ISBN: 950-12-6526-9 